\title{
Using technology to encourage social problem solving in preschoolers
}

\author{
Mandy B. Medvin, Diana Reed, Deborah Behr and Elizabeth Spargo \\ Westminster College, New Wilmington, PA 16172-0001, US; CDI Head Start Serving Lawrence \\ County, 301 E. Long Ave., New Castle, PA 16101 medvinm@westminster.edu; \\ reedd@westminster.edu; behrd@westminster.edu
}

\begin{abstract}
A recent emphasis in the early childhood literature has been on using computers to facilitate social skills in preschool children. Findings are mixed on how well children collaborate when using computers. This inconsistency indicates that the design of the computer curriculum may dictate the nature of the climate of use.

Our work examines a cooperative classroom approach to computer use to "alter" the roles of students and teachers. Our premise is that computers can encourage socialization among children, thereby forming the basis for early cooperative learning.
\end{abstract}

Key words: collaboration, teacher education, early childhood education, social contexts

\section{INTRODUCTION}

Do computers isolate? Or do they encourage interaction among preschool children? Some research shows that children enjoy working with one another on the computer by making suggestions, playing games together, and providing assistance (Davidson 1989; Shade, Nida, Lipinski, and Watson 1986; Muller and Perlmutter 1985). Other studies find that children are aggressive in obtaining access to the computer, and that the play is competitive rather than cooperative (Anderson 1998). Our premise is that the design of the classroom environment can encourage either isolation or integration. The goal of our project was to make the computer a "social

The original version of this chapter was revised: The copyright line was incorrect. This has been corrected. The Erratum to this chapter is available at DOI: 10.1007/978-0-387-35668-6_17 
center" in our classroom, and to test our approach by extending it across two very different preschool settings: A university preschool laboratory and a specially designed Head Start preschool for disadvantaged children.

We chose this approach for several reasons. First, our school emphasizes a Vygotskian approach to learning with peer interaction as a means of promoting social and cognitive development. According to Vygotsky (1978), “... human learning presupposes a specific social nature and a process by which children grow into the intellectual life of those around them..." (88). We do not separate social and cognitive functions but examine them together as a framework for learning. We are also inspired by socio-cultural models of cognition, where children attain learning goals via scaffolding (Greenfield 1984; Woods and Woods 1996) or "guided participation" by adults or peers (Rogoff 1990; 1995).

Second, many studies indicate that preschool is an important time for the development of peer relations, which in turn form the cornerstone for children's later life success (Parker and Asher 1987). For example, children who play cooperatively in preschool and transition to kindergarten with a familiar peer have an easier time adjusting to school (Ladd and Price 1987). Our idea is that the skills that predicate higher social success in preschool can be enhanced by participation in collaborative tasks.

Finally, since many children consider computers exciting and fun (McBride and Austin 1986), we theorised that the computer station might provide a common focus for less social children to be involved in the classroom social network. Our own anecdotal observations of what occurs in our school when children gather together around the computer are reflected in this paper.

\section{PEER COLLABORATION IN YOUNG CHILDREN: RESEARCH PERSEPCTIVES}

A large body of research supports the idea that peer collaboration can lead to advances in cognitive understanding given the appropriate design of tasks and scaffolding on the part of the teacher. The majority of studies have focused on carefully designed laboratory experiments which pair peers on a type of collaborative task rather than examining natural interactions in the classroom. Findings from the research, however, may be helpful in thinking about setting up a facilitative classroom environment.

Factors that influence preschool peer collaboration include age, expertise, and type of task. Cooper (1980) demonstrated that older children were more successful than younger preschoolers on a matching task due to higher levels of on-topic conversational directives. Azmitia (1988) showed that same-age 
novices working with an expert improved more than novices working alone or in pairs on a Lego model task. Holmes (1997) found a greater exchange of information on a more complex model task than a single bead task. In addition, girls who used reasoning on complex tasks had higher task success than those who did not, while boys who used reasoning had greater success on a simpler bead task. The overall findings indicate that preschool children can collaborate successfully and show improved task performance in pairs versus working individually. Therefore, it is worthwhile to explore the use of collaboration when working on computers in the preschool classroom.

\section{OUR COLLABORATION}

To ensure a variety of ideas and mutual involvement in the project, a series of meetings were conducted at different points during the project between Head Start and the Westminster College laboratory preschool staff. Our initial intervention focused on a classroom of eighteen 4 and 5 year olds at the laboratory preschool, and two classrooms of eighteen 3 to 5 year olds each at the Head Start site. Video cameras were placed in each school to document children's interactions at the computer and the same programs were used at both sites. In addition, we received a National Association for the Education of Young Children (NAEYC) Membership Action Grant to develop a teacher training workshop for daycare and preschools in our area.

\subsection{Experiences at the lab preschool: Our initial site}

The Westminster College laboratory preschool, located in rural western Pennsylvania, serves a relatively middle-class population from the surrounding area. Many of our families have a computer at home. Prior to the intervention, preschool volunteers took children out of the classroom to work individually with the computers in a nearby computer lab.

We purchased a computer and moved it into the preschool classroom. To facilitate social interactions, we placed it in an area that was convenient but not too busy (Davis and Shade 1994), and put several chairs at the center so children could work together. We used several activities to acquaint children with computers and the programs, so they could more easily assist one another at our centre. A guest speaker introduced the computer and opened it up so we could look inside. Children played directional games using a large cardboard "mouse" and participated in "fun" art activities, such as painting using old floppy as well as creating computer wire art. Finally, we familiarized small groups of students with several computer games from Millie's Math House (Edmark 1992), which we then used at our center. 


\subsection{Facilitating cooperative use of computers}

We introduced three rules to encourage social usage, sharing, and helping behavior at the computer - Find a Friend, Help a Friend, and Share the Mouse - to facilitate children's social problem solving in order that "individual skills originate in cooperative activity through a scaffolding process" (Greenfield 1984). The Find a Friend rule means that two or more children must be playing at the computer at all times. Help a Friend encourages children to stay and help the child with the mouse, play the computer program by providing directions and information, by pointing, and by physically helping to guide the mouse. Share the Mouse prompts children to pass the mouse to the friend next to them after they have played for a while. Children are encouraged to "use their words" and switch chairs to help with taking turns. We also took pictures of students engaged in the three activities and posted the rules by the computer as a reminder.

Children immediately seemed to enjoy working at the computer together though they needed some assistance to follow the rules. Initially, a teacher stayed at the center to help them, and to encourage them to work out conflicts and provide support. For example, if a child asked the teacher for help in changing the computer game, the teacher might say, "I know Jennie has played that game before. If you ask her, I'm sure she'll tell you where to click the mouse to change the game." The teacher also encouraged children to point to the picture prompts and remind their friends of the rules.

As the children needed less guidance the teachers gradually spent less time at the computer. Woods and Woods (1996) said that "... effective guidance involves the transfer of responsibility from (teacher) to learner." The computer became a peer-led center. Children spontaneously offered assistance to their friends in changing the game and exploring the programs. The children helped each other play new games as well. Some students had the same games at home and were able to assist their peers. At other times they simply problem solved until they found the solution.

Sharing was a difficult task and was often mediated by the teacher. The children, however, developed their own strategies for deciding who went next. Eventually, we introduced a timer to assist children in deciding when it was someone else's turn, which worked well. This approach was so successful that we next examined this model at the Head Start site.

\subsection{Reactions from the Head Start site}

The Villa Maria Head Start program, located in the same county as the laboratory preschool, serves children from low-income families in the surrounding rural area. At least ten percent of the children have special needs 
and often that percentage is higher. Few of the children had access to computers prior to entering our program. Our goal was the same as the preschool lab - to change the computer station to a more cooperative centre.

Our strategies to encourage social interaction were different from the laboratory preschool since we thought the Head Start children would benefit by a more structured approach. To facilitate sharing, we used a sign-up sheet to let children know when it was their turn. We placed the children in small groups of three or four, and strategically matched quiet children with more talkative ones to promote language use. Often children not on the list would join the sessions until a crowd formed around the computer.

We found that the larger group sizes resulted in more socialisation and mediation taking place at the computer without the potential problems that we had imagined might occur, such as impatience while waiting turns with the mouse and a short attention span if the child wasn't actually manipulating the mouse. Children were very engaged, offering suggestions to the computer user, and they often learned the program by watching the game being played. By helping the user, the waiting children felt a part of the process, which made the wait more tolerable and helped increase the children's patience.

We also found that the computer provided a positive outlet for the more dominant personalities in our classroom. Children used their natural leadership abilities and temperament in a positive manner that was well accepted by peers. Also, the group work provided a great opportunity for children who were usually passive to develop leadership skills by instructing others on the computer. Children helped peers who were younger or had motor difficulties in moving the mouse.

Almost half of the children were receiving speech and language therapy. Working at the computer with peers seemed to provide a common focus that encouraged social interaction and language use. For example, in one session Joan spent most of the time silently sitting on the facilitator's lap while watching the screen. Then, after taking a turn at the mouse with the assistance of Steve and Alfonse, she helped a younger child move the mouse and verbally "figure out" the program. At the laboratory school we found that one child with language delays taught other children how to use a game he had at home.

Overall, we found that children "took over" the computer station at both sites with some guidance thus employing a peer collaborative model. Other studies report similar findings and indicate that the computer may foster more interaction than other areas of the preschool classroom (Muhlstein and Croft 1986; Muller and Perlmutter 1985). 


\section{ACCOMPLISHMENTS AT BOTH SITES}

What were the major accomplishments of the children and why did they happen? In addition, how did the differences in techniques between the two sites influence outcomes?

Over time, the accomplishments at both sites were similar for the children, regardless of differences in background or experience with computers: (1) initially students offered to help and seemed to enjoy the idea of helping others at the computer; (2) children using the mouse learned after some practice to ask their peers for help if they needed it and refused assistance less often over time; they began to collaborate with their peers, and the help offered was more appropriate to the task at hand; (3) sharing required more facilitation by teachers than helping, though teacher facilitation gradually decreased; still, over half the time children settled sharing issues without the help of the teacher; (4) new friendships were formed as children who did not normally play together realised each other's strengths and competencies.

We believe that there were several causal agents making this approach successful: (1) the approach fit our current philosophy of facilitating cognitive development in a social context and was an extension of goals at other centres; (2) teachers already have experience facilitating social skills and so this approach built on already existing abilities; (3) we continued to monitor the computer groups to help enhance children's skills; (4) children are highly motivated to work on the computer and thus will be more interested to fill required roles in order to play. In essence, to obtain access to the computer, they must be social.

\section{CONCLUSION}

Researchers have questioned the use of computers in the preschool classroom, indicating that high levels of adult assistance are needed, child control is decreased, play is diminished and peers become isolated (Henninger 1994). Our results indicate that with some initial facilitation it is the children who "run" the computer center, becoming experts in using the programs, collaborating and assisting each other. Teachers were comfortable with this approach, as it affirmed their models for how preschool classrooms should operate. Thus computers, when used appropriately, have the potential to facilitate the development of important social skills needed for entry into kindergarten. We also feel strongly that it is not how many computers you have but what you do with them that makes the difference in the preschool classroom. 


\section{REFERENCES}

Anderson, G. T. (1998) Comparison of the types of cooperative problem-solving behaviors in four learning centers. Poster presentation at Head Start's Fourth National Research Conference. Washington, D.C.

Azmitia, M. (1988) Peer interaction and problem solving: When are two heads better than one? Child Development 59 87-96.

Cooper, C. R. (1980) Development of collaborative problem solving among preschool children. Developmental Psychology 165 433-440.

Davidson, J. (1989) Children and Computers Together in the Early Childhood Classroom. New York: Delmar.

Davis, B. C. and Shade, D. D. (1994) Integrate, don't isolate! Computers in the early childhood curriculum. ERIC Digest (December). No. EDO-PS-94-17.

Greenfield, P. M. (1984) A theory of the teacher in the learning activities of everyday life. In B. Rogoff and J. Lave (eds.) Everyday Cognition: Its Development in Social Context Cambridge: Harvard University Press 117-138.

Henniger, M. L. (1994) Computers and preschool children's play: Are they compatible? Journal of Computing in Childhood Education 53 231-239.

Holmes, H. A. (1997, April) Preschool children's collaborative problem-solving interactions: Influence of task, partner gender, and conversational style. Poster presentation at the biennial meeting of the Society for Research in Child Development. Washington, D.C.

Ladd, G. W. and Price, J. M. (1987) Predicting children's social and school adjustment following the transition from preschool to kindergarten. Child Development 58 1168-1189.

McBride, K. J. and Austin, A. M. (1986) Computer affect of preschool children and perceived affect of their parents, teachers, and peers. The Journal of Genetic Psychology $1474497-$ 506.

Millie's Math House. (1992) Redmond, WA: Edmark Corporation.

Muller, A. A. and Perlmutter, M. (1985) Preschool children's problem-solving interactions at computers and jigsaw puzzles. Journal of Applied Developmental Psychology 6 173-186.

Muhlstein, E. A. and Croft, D. J. (1986) Using the microcomputer to enhance language experiences and the development of cooperative play among preschool children. Cupertino, CA: De Anza College. ERIC Document Reproduction Service No. ED269 004.

Parker, J. D. and Asher, S. R. (1987) Peer relations and later personal adjustment: Are lowaccepted children at risk? Psychological Bulletin 1023 357-389.

Rogoff, B. (1990) Apprenticeship in Thinking: Cognitive Development in Social Context. New York: Oxford University Press.

Rogoff, B. (1995) Observing sociocultural activity on three planes: Participatory appropriation, guided participation, and apprenticeship. In J.V. Wertsch, P. del Rio, and A. Alvarez (eds.) Sociocultural Studies of Mind. New York: Cambridge University Press.

Shade, D. D., Nida, R. E., Lipinski, J. M. and Watson, J. A. (1986) Microcomputers and preschoolers: Working together in a classroom setting. Computers in the School 32 53-61.

Tharp, R. G. and Gallimore, R. (1991) Rousing Minds to Life: Teaching, Learning, and Schooling in Social Context. New York: Cambridge University Press.

Woods, D. and Woods, H. (1996) Vygotsky, tutoring and learning. Oxford Review of Education 221 5-16.

Vygotsky, L. S. (1978) Mind in Society. Cambridge, MA: Harvard University Press. 


\section{BIOGRAPHIES}

Mandy Medvin is an associate professor of Psychology at Westminster College in New Wilmington, PA, and director of the Preschool Lab program. She has presented at workshops and conferences on the social use of computers.

Diana Reed is headteacher and Deborah Behr is a teacher at the Westminster College Preschool Lab. They regularly present at workshops on encouraging social development in young children.

Elizabeth Spargo is educational director of CDI Head Start serving Lawrence County and is a regular presenter at workshops. 